\title{
8. SITE SURVEYS IN THE SOUTH PACIFIC WITH A SEABEAM SWATH-MAPPING SYSTEM1
}

\author{
Peter Lonsdale, Scripps Institution of Oceanography ${ }^{2}$
}

\begin{abstract}
Four $500-\mathrm{km}^{2}$ areas along latitude $19^{\circ} \mathrm{S}$ were surveyed to help select drill sites for DSDP Leg 92 . Three were areas of abyssal hills on the west flank of the East Pacific Rise. The fourth was on older crust that had accreted at the ancestral Pacific-Farallon spreading center. Principal survey tools were a Seabeam multi-narrow-beam echo sounder, which mapped highly lineated fault-block terrains with local volcanic relief, and seismic profilers, which allowed an estimate of sediment thickness. Magnetic profiles in and between the surveys established the crustal age at each site.
\end{abstract}

\section{INTRODUCTION AND METHODS OF STUDY}

Most of the drill sites for Leg 92 were targeted in a remote and relatively unexplored region between the Tuamotu Archipelago and the crest of the East Pacific Rise. The objective was to sample typical sections of crust that had accreted at fast-spreading rises during the past 30 m.y. and had not been overprinted by off-axis seamount volcanism. Site surveys were required to identify such areas and to establish their age and the thickness and continuity of sediment cover. These surveys also indicated the structural setting of the heat flow and pore water measurements used to define precise drilling targets.

The systems used on the survey vessel Thomas Washington were a newly installed Seabeam multi-beam echo sounder, a $3.5-\mathrm{kHz}$ acoustic profiler, a single-channel seismic profiler using a 40 -in ${ }^{3}$ air gun as the sound source, and a proton-precession magnetometer. Navigation was by transit satellite, with the track interpolated between fixes by a sophisticated dead-reckoning program. For the survey areas this interpolation was improved by matching swaths of Seabeam contours where they overlap on adjacent or crossing tracks.

The Seabeam system (Renard and Allenou, 1979) provides a swath of 16 narrow-angle $\left(2.7^{\circ}\right)$ sonar beams which cover a cross-track distance equal to about twothirds of the water depth. On this first cruise of the Scripps system we experienced some problems with data from the outer beams. In particular, the system frequently tracked and displayed the sidelobe response of the central beam instead of the signal from the outer beams. The result was a well developed "tunnel effect" (Moustier and Kleinrock, in press), in which flat, smooth seafloor is represented as a trough with the ship's track along its axis. This failure of the system's sidelobe rejection scheme, which depends on the correct setting of echo-processing thresholds, was caused mainly by operator inexperience; artifacts are most marked on our first two surveys (Sites I and II), where considerable post-

\footnotetext{
1 Leinen, M., Rea, D. K., et al., Init. Repts. DSDP, 92: Washington (U.S. Govt. Printing Office).

2 Address: Geological Research Division (A-005), Scripps Institution of Oceanography, University of California at San Diego, La Jolla, CA 92093.
}

cruise processing and the elimination of spurious data were required to produce the final charts. As we learned more about the operational characteristics of the system and moved into rougher terrain, this problem was overcome, and the raw data from Sites III and IV are much cleaner. The seismic records also contain numerous instrumental artifacts from bubble-pulses and multiple echoes, but these are more familiar and easily recognized.

Our survey strategy was to run an east-west survey line from the Tuamotus to the crest of the East Pacific Rise, monitoring the crustal age along this transect by identifying measured magnetic anomalies with the reversal time scale and anomaly nomenclature of Ness et al. (1980). As our track crossed crust of the age desired for drilling $(30,10,5$, and $2 \mathrm{Ma})$, our contour swath and profiles were scanned for a suitable site; when we found one, a survey pattern was run to cover a $500-\mathrm{km}^{2}$ area straddling the west-east transect. At the end of this survey, acoustic transponders were deployed to serve as navigational benchmarks for the subsequent drilling. We completed four surveys, on crust aged 27.6, 8.0, 4.7, and $2.0 \mathrm{Ma}$; only the three oldest sites were eventually drilled on Leg 92.

\section{REGIONAL SETTING AND TECTONIC HISTORY}

At the latitude of our surveys the age of the East Pacific Rise is less than $20 \mathrm{Ma}$. Older crust accreted at a segment of the Pacific-Farallon plate boundary called the Mendoza Rise (Mammerickx et al., 1980). The breaking of the Farallon Plate was followed by (1) the reorientation of the spreading center so that it was orthogonal to a new direction of relative plate motion, and (2) a westward jump of the spreading center that abandoned the Mendoza Rise as a fossil on the new Nazca Plate. On our Seabeam transect (Fig. 1), the boundary between these spreading regimes, referred to as the "J-line" by Okal and Bergeal (1983), is at $129^{\circ} \mathrm{W}$, where it is readily identified by a change in abyssal-hill orientation and by a topographic step which is caused by the absence, at this latitude on this west flank, of crust aged between about 27 and $19 \mathrm{Ma}$. This location is more than $500 \mathrm{~km}$ west of the location predicted by Okal and Bergeal's (1983) model for the tectonic evolution of the region.

The other major tectonic event recorded by our transect is the growth of a major seamount chain, with an 

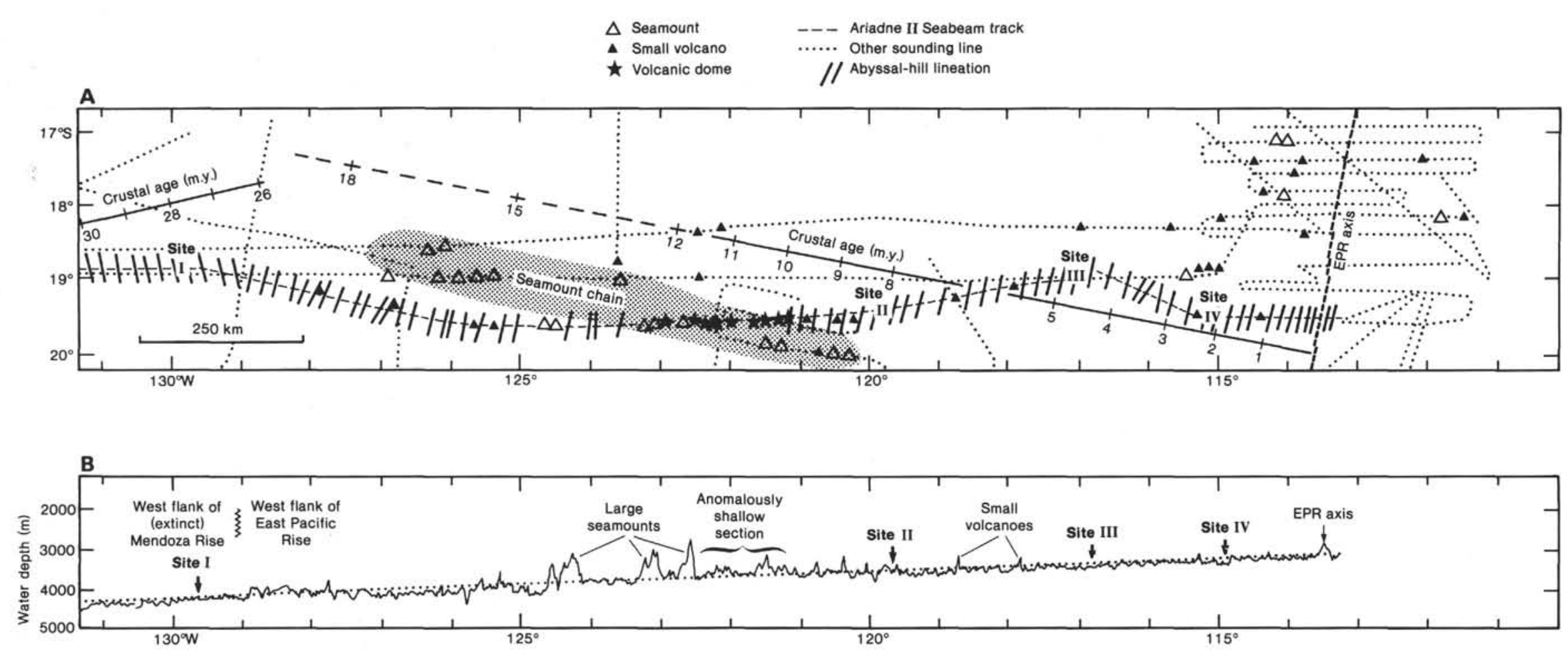

Figure 1. A. Location of survey sites and intervening track, Ariadne Leg II. Crustal ages are inferred from the magnetic anomalies in Figure 2. B. West-east projection profile along the center beam of the Seabeam swath. Dotted line shows subsidence curve in meters, $z$, calculated by $z=3000+230 \sqrt{T}$, where $T$ is estimated crustal age in millions of years. Vertical exaggeration is $\times 60$. 
orientation appropriate for a hot spot chain, across the older part of the East Pacific Rise flank. Our oblique crossing of this chain between $124.5^{\circ}$ and $121^{\circ} \mathrm{W}$ (Fig. 1) included several 1-km-high seamounts and numerous low, circular domes that may result from laccolith intrusions (Lonsdale, 1983). No lineated abyssal hills were mapped in this region, presumably because the plate fabric has been buried by subsequent volcanism. A few of the domes have small parasitic cones with very fresh, apparently unsedimented, craters (Lonsdale, 1983, fig. 3), features that indicate that the part of the chain we crossed, which seems to be near its southeast end, may be quite young. Because of the likelihood that the thermal regime and hydrothermal circulation have been perturbed by offaxis volcanism, this area was considered unsuitable for Leg 92 drilling, and no site surveys were conducted.

West-flank spreading rates, derived from an interpretation of magnetic anomalies along our transect and adjacent tracks (Fig. 2), are estimated at $70 \mathrm{~mm} / \mathrm{yr}$. for the 33- to 27-Ma crust accreted at the Mendoza Rise, and $77 \mathrm{~mm} / \mathrm{yr}$. for 12- to 1-Ma crust accreted at the East Pacific Rise. Unambiguous indentification of anomalies on the older half of the East Pacific Rise is not possible, probably in part because of the effects of off-axis volcanism, but extrapolation of the $77-\mathrm{mm} / \mathrm{yr}$. rate gives an age for the "J-line" of about $19 \mathrm{Ma}$, the same as the age estimated from other data by Mammerickx et al. (1980). Except for the area overprinted by the seamount chain, the west flank of the East Pacific Rise has subsided very regularly as its lithosphere cooled; the topographic profile is fitted well by a single $\sqrt{T}$ curve (Fig. 1), where $T$ is estimated crustal age in millions of years.

\section{SITE SURVEYS}

\section{Site I (DSDP Site 597)}

This site survey (Fig. 3A) straddles the young margin of Anomaly 9 (Fig. 2); that is, crustal age is $27.6 \mathrm{Ma}$ (time scale of Ness et al., 1980). In terms of topography, the area is a slightly rolling plain with a $50-\mathrm{m}$ abyssalhill relief lineated with a strike of $355^{\circ}$. In the southern part of the area there are a few small (100-m) volcanic peaks (e.g., those on line G-H in Fig. 3B).

There is a rather uniform blanket of unconsolidated sediments, with an average thickness of about $0.07 \mathrm{~s}$ (estimated to represent 50 to $60 \mathrm{~m}$ ). Acoustic basement is very strong and unusually smooth. Steep volcanic peaks rise above this smooth reflector (e.g., those near B and C, Fig. 3B). Outcrops exposing igneous rock at the seafloor probably occur near G. Immediately west of the survey, near A in Figure 3B, the sediment cover thins rapidly and disappears; presumably it has been removed by erosion. Since the presence of a fairly uniform blanket was a requirement for the drill site, a slightly younger area was chosen in preference to the 30 -Ma site originally targeted.

\section{Site II (DSDP Site 599)}

This survey site lies on the young half of Anomaly $4.1^{\prime}$ (Fig. 2) and is therefore estimated to be $8 \mathrm{Ma}$ in age. This crust is younger than that originally targeted (10 Ma); it was chosen as a survey site to avoid the seamount chain that occupies 10-Ma crust at this latitude. The site has a typical abyssal-hill topography (Fig. 4A), with lineated fault-block hills striking $010^{\circ}$, on which small volcanic hills have been superimposed. The hills have been smoothed by sedimentation. Normal abyssalhill relief in this region is up to $200 \mathrm{~m}$ (see line A-B, Fig. 4B), but in the central part of the survey, between the ends of overlapping fault blocks, there is a $20-\mathrm{km}^{2}$ smooth patch with less than $25 \mathrm{~m}$ of relief.

The steep sides of many of the fault blocks seem, on the $3.5-\mathrm{kHz}$ and air gun profiles (Fig. 4B), to expose basement rocks. The central flat patch has a fairly uniform blanket of unconsolidated sediment cover about $0.05 \mathrm{~s}(35$ to $40 \mathrm{~m})$ in thickness. Sediment estimated to be as much as $50 \mathrm{~m}$ thick occurs in the floors of some abyssal-hill troughs (e.g., those near A and D, Fig. 4B).

\section{Site III (DSDP Sites 600 to 602)}

This site is situated on Anomaly 3.4 (Fig. 2), which has an estimated age of 4.8 to $4.6 \mathrm{Ma}$. It includes a region of unusually smooth relief within a typical lineated abyssal-hill terrain, best mapped in the southern and western parts of Figure 5A, which strikes $015^{\circ}$. The flatter area is divided by an 80 - to 150 -m scarp, also striking $015^{\circ}$, into a $6-\mathrm{km}$-wide basin and a $6-\mathrm{km}$-wide plateau. The transponders were deployed on this plateau. The lineated hills east of the transponder array are somewhat unusual in that they are narrow and sharp-crested and look more like constructional volcanic ridges than the abyssal-hill horsts characteristic of the region.

A substantial sediment cover, estimated at 20 to $30 \mathrm{~m}$ from both the $3.5-\mathrm{kHz}$ and seismic reflection profiles (e.g., Fig. 5B), occurs only on the plateau. It is rather surprising, but the adjacent basin has less sediment, a maximum of only about $10 \mathrm{~m}$ being inferred from 3.5 $\mathrm{kHz}$ records. Basement no doubt crops out over extensive areas of the sides of abyssal hills, especially on the steep ridges east of the transponders. It probably also crops out along the step between the basin and the plateau.

\section{Site IV (not drilled)}

This youngest survey site occupies the older margin of Anomaly 2, which is dated 2.1 to $1.9 \mathrm{Ma}$. It has typical young lineated abyssal-hill terrain with about $250 \mathrm{~m}$ of fault-block relief (Fig. 6), except that near $19^{\circ} 30^{\prime} \mathrm{S}$, $114^{\circ} 58^{\prime} \mathrm{W}$, where most of the heat flow and gravity-coring stations were made, there is considerable nonlineated volcanic relief. At the east side of the survey there is an anomalously shallow ridge rising above $3000 \mathrm{~m}$; the ridge was probably also built by volcanic construction.

The $3.5-\mathrm{kHz}$ records indicate that there are abundant rock outcrops, with significant patches of sediment occurring only as shallow ponds in the troughs. The thickest ponds tend to be near the greatest relief: in the vicinity of the heat flow and coring survey, maximum thickness is 10 to $15 \mathrm{~m}$, but farther west, beside the shallow ridge, there is a pond with 20 to $30 \mathrm{~m}$ of sediment. 


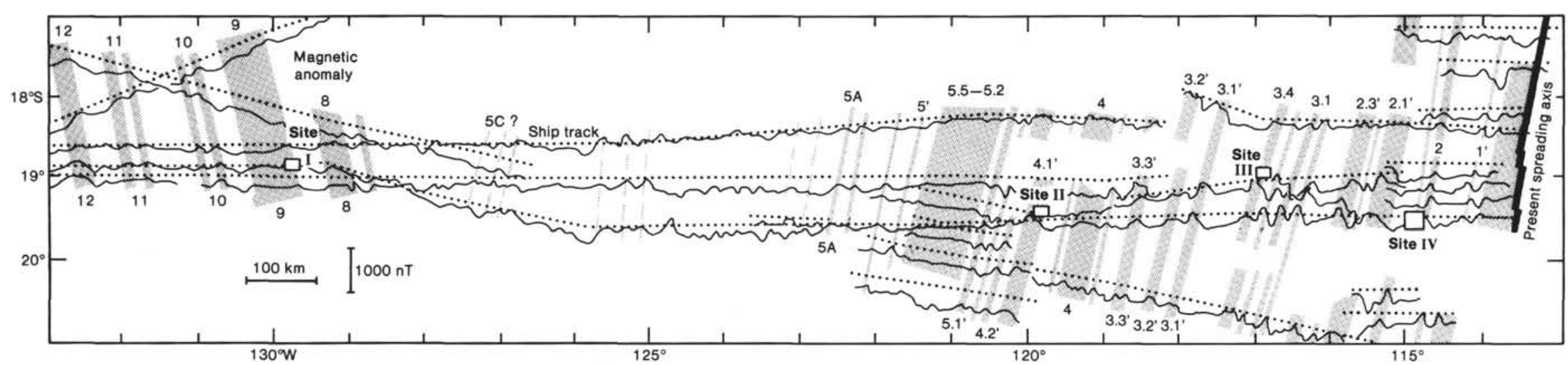

Figure 2. Magnetic anomalies along the Ariadne II and adjacent tracks, with an interpretation in terms of the magnetic reversal time scale (shaded strips are positively magnetized crust). 


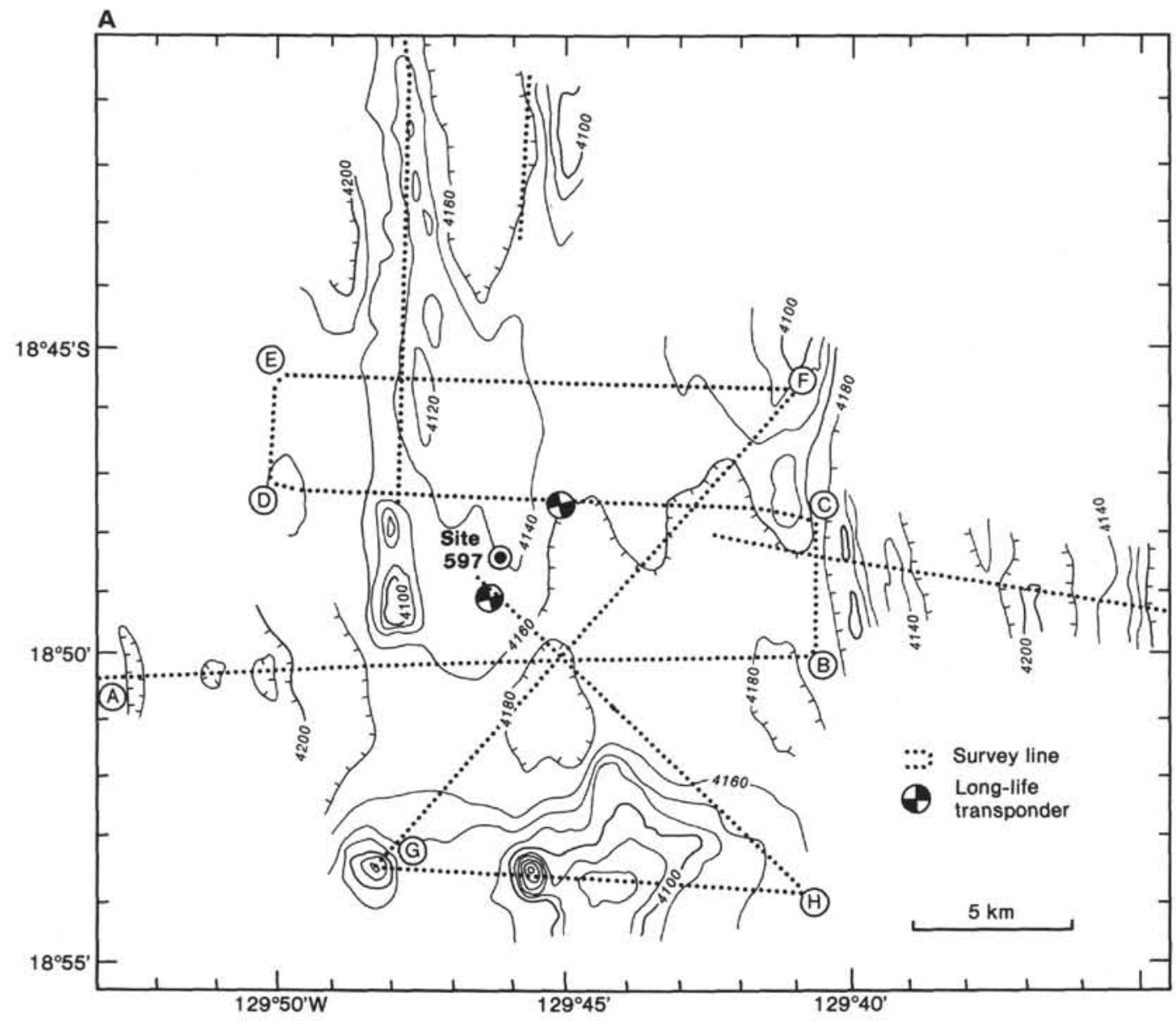

Figure 3. A. Bathymetry of Site I, from Seabeam site survey data. Contour interval is $20 \mathrm{~m}$. Lettering shows location of profiles in (B). B. Seismic reflection profiles, from a single-channel 40 -in. ${ }^{3}$ air gun system, at Site I.
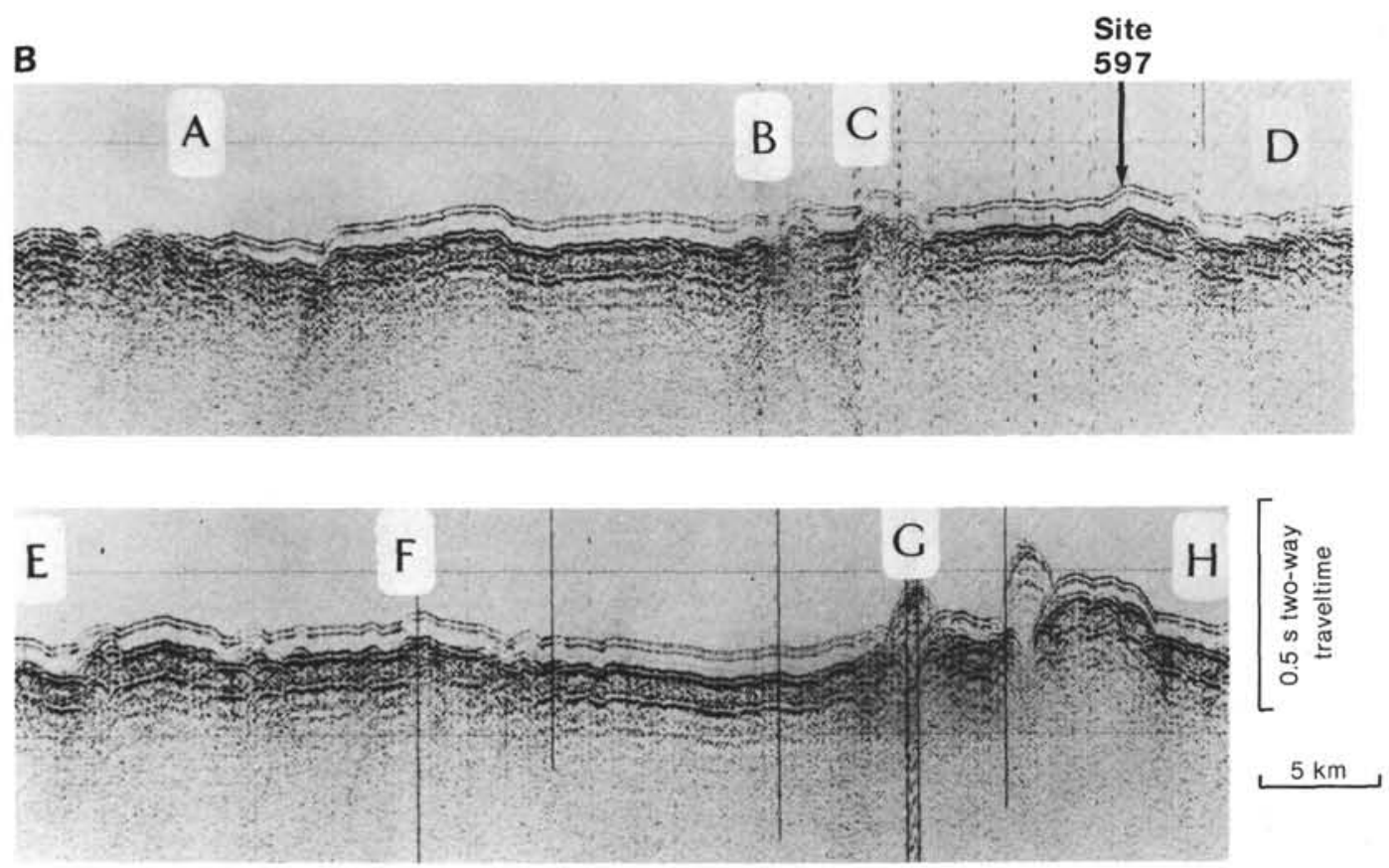


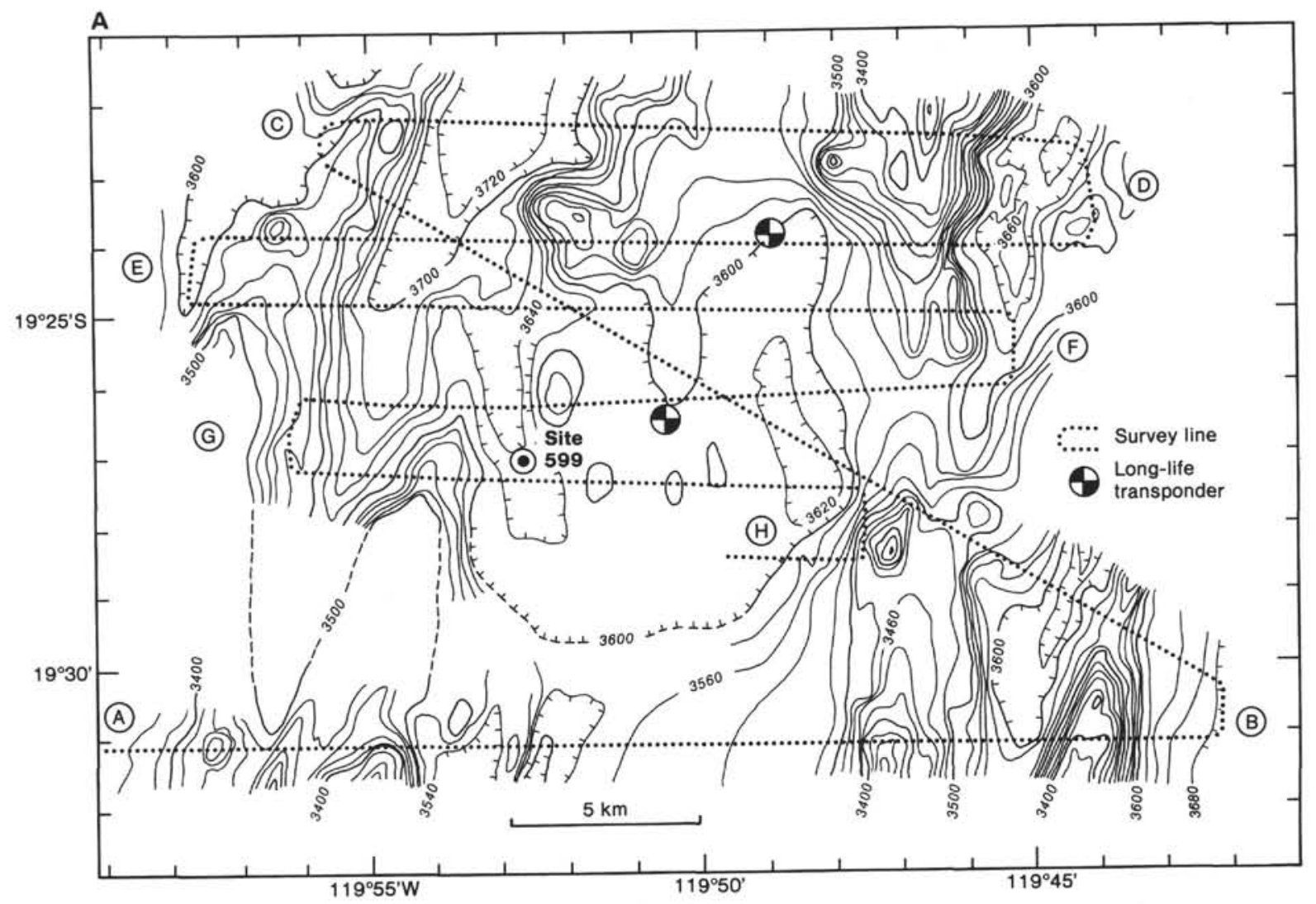

Figure 4. A. Bathymetry of Site II, from Seabeam site survey data. Contour interval is $20 \mathrm{~m}$. Lettering shows location of profiles in (B). B. Seismic reflection profiles, from a single-channel 40 -in. ${ }^{3}$ air gun system, at Site II.
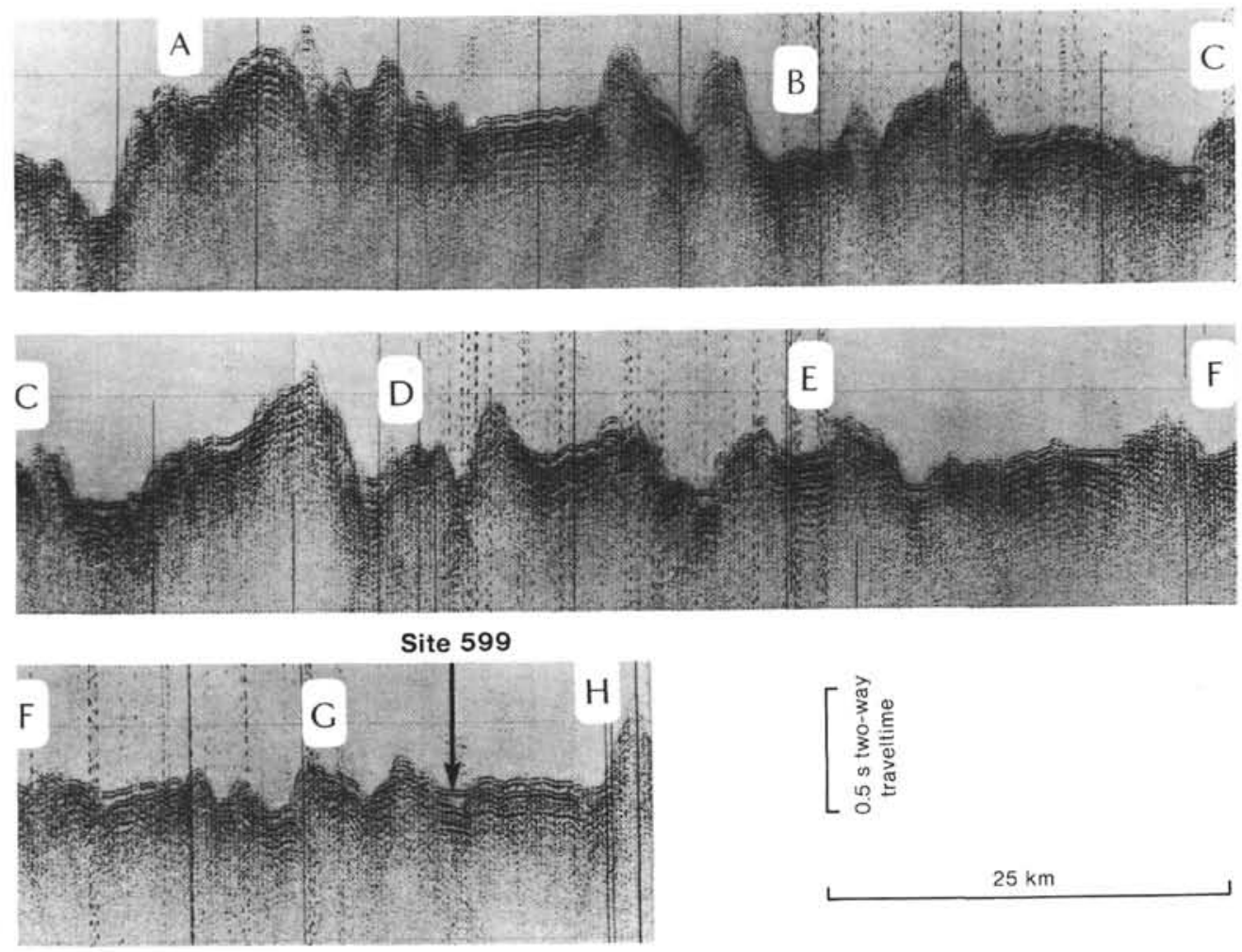

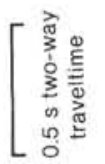

Figure 4 (continued). 


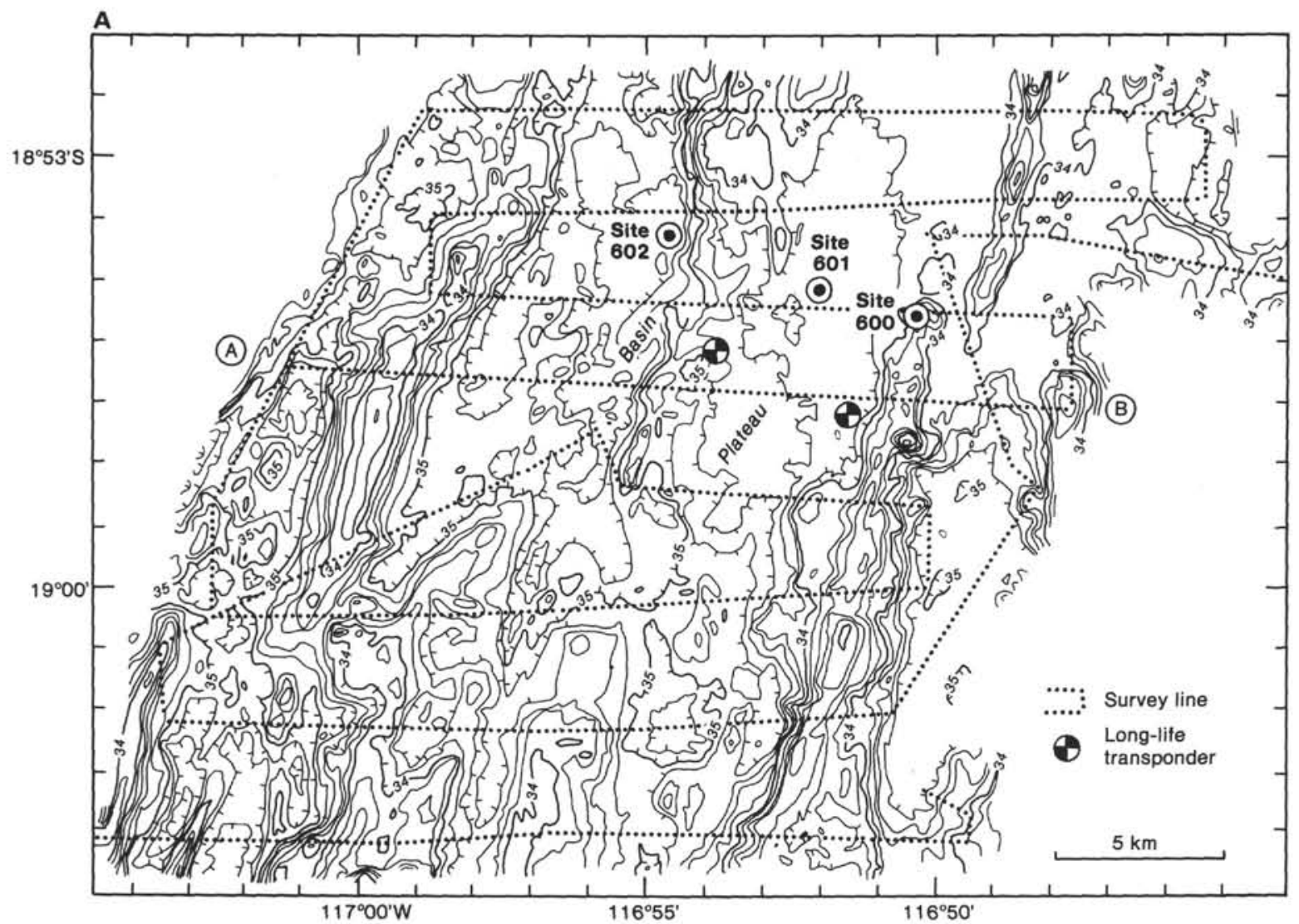

Figure 5. A. Bathymetry (in hundreds of meters) of Site III, from Seabeam site survey data. Contour interval is $20 \mathrm{~m}$. Lettering shows location of profile in (B). B. Seismic reflection profile across the center of Site III.

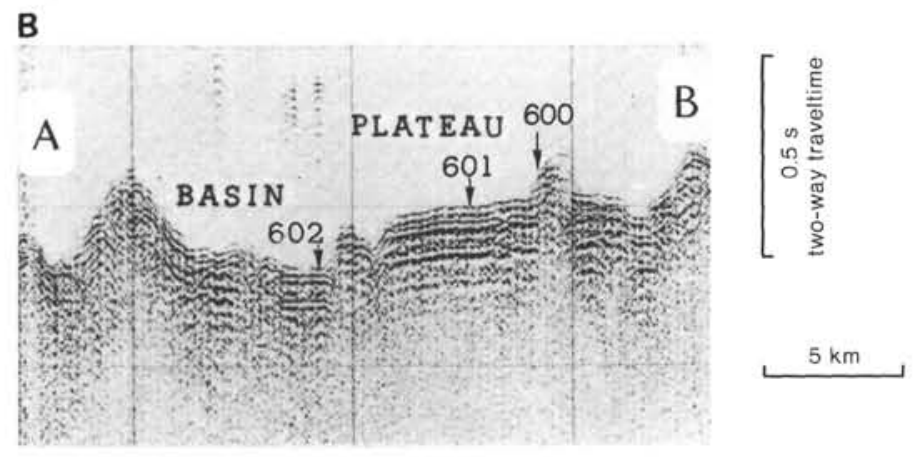

Figure 5 (continued).

\section{ACKNOWLEDGMENTS}

These site surveys were funded by J. O. I. Subcontract $46-81$. The work at sea was accomplished with the help and cooperation of Capt. C. Johnson and the crew of R/V Washington, and the entire scientific party of Expedition Ariadne Leg II. I am particularly grateful to J. L. Abbott and the Scripps Shipboard Computer Group, which he leads, for getting the Seabeam system and its data-processing programs operational in record time.

\section{REFERENCES}

Lonsdale, P., 1983. Laccoliths and small volcanoes on the flank of the East Pacific Rise. Geology, 11:706-709.

Mammerickx, J., Herron, E., and Dorman, L., 1980. Evidence for two fossil spreading ridges in the southeast Pacific. Geol. Soc. Am. Bull., 91:263-271.
Moustier, C. de, and Kleinrock, M. C., in press. Bathymetric artifacts in Sea Beam data: how to recognize them, what causes them. $J$. Geophys. Res.

Ness, G., Levi, S., and Couch, R., 1980. Marine magnetic anomaly timescales for the Cenozoic and Late Cretaceous: a precis, critique and synthesis. Rev. Geophys. Space Physics, 18:753-770.

Okal, E. A., and Bergeal, J. M., 1983. Mapping the Miocene Farallon Ridge jump on the Pacific plate: a seismic line of weakness. Earth Planet. Sci. Lett., 63:113-122.

Renard, V., and Allenou, J. P., 1979. Sea Beam, multi-beam echosounding in "Jean Charcot". Internat. Hydrographic Rev., 56:3567.

Date of Initial Receipt: 6 February 1985 Date of Acceptance: 9 March 1985 


\section{P. LONSDALE}

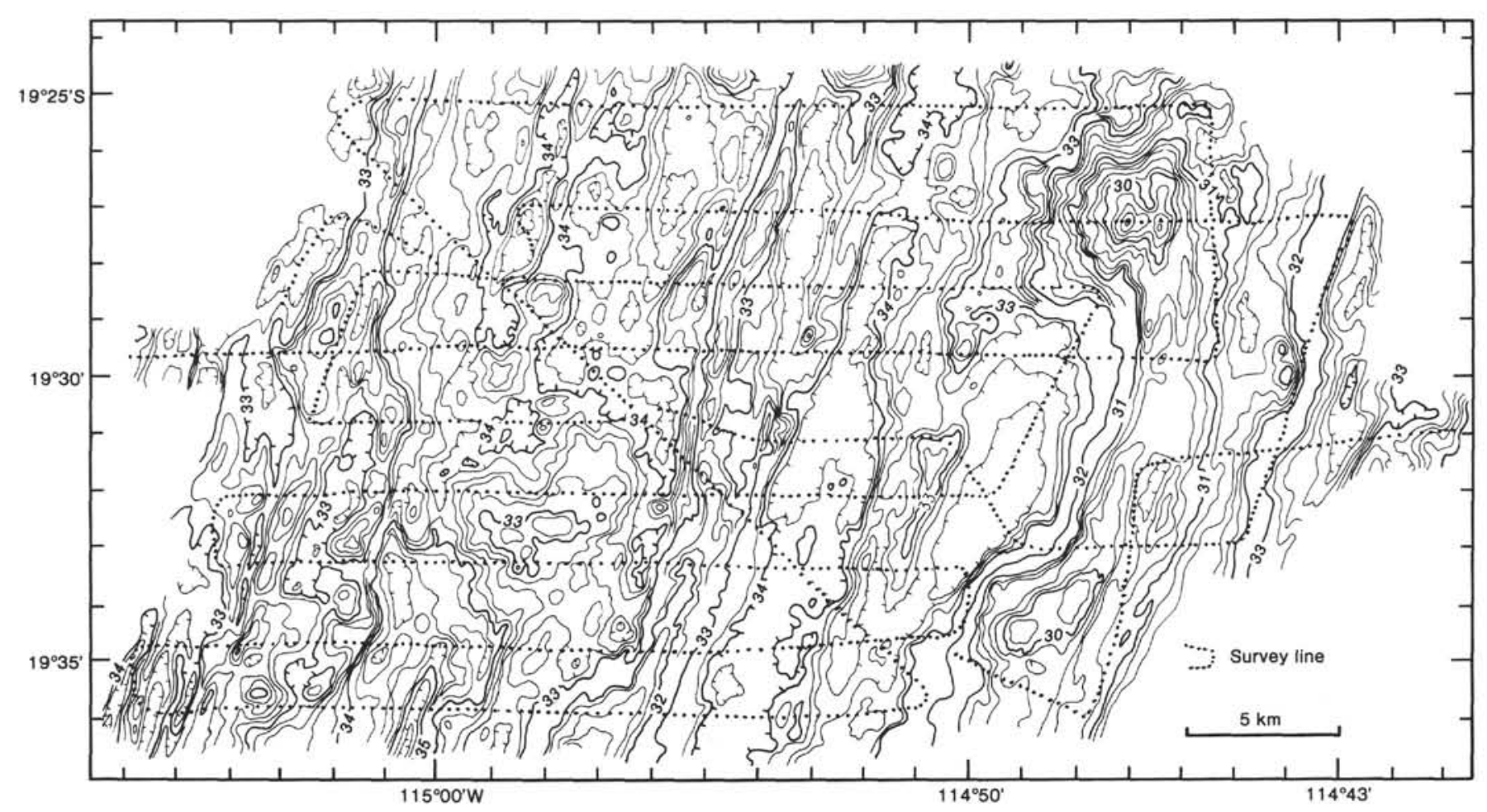

Figure 6. Bathymetry (in hundreds of meters) of Site IV, from Seabeam site survey data. Contour interval is $20 \mathrm{~m}$. 